\title{
CFD Anlysis of Pulverised-Coal Combustion of Burner Used In Furnace with Different Radiation Models
}

\author{
Rajesh Holkar ${ }^{1}$, Dr. Omprakash. D. Hebbal ${ }^{2}$ \\ Department of mechanical engineering, PDA College of engineering, Gulbarga.
}

\begin{abstract}
Pulverized coal is an important fuel for electricity production and will continue to be important for decades. Since coal is a natural resource that depends on many factors and parameters, it has variable properties and composition. Combustion chamber designers Endeavour to achieve optimum operating conditions that give maximum combustion efficiency, together with minimum pollutant formation rate. Modeling of fossil fuel utility boilers has reached a remarkable development in recent years. Particularly, the application of computational fluid dynamics (CFD) modeling technology and other advanced mathematical methods offer opportunities for analysis, optimization and options examination in order to increase the overall efficiency of the energy facilities. The main objective of the present work was to investigate how the results obtained with two radiative heat transfer methods, the P1 approximation method, Discrete Transfer and the discrete ordinates (DO) method using ANSYS FLUENT, fit temperature field in a boiler furnace on pulverized coal, with implemented over-fire air (OFA) ports. The overall framework of the CFD modeling approach is described. The numerical modeling results for boiler baseline operating conditions are compared with a test data of temperature measurements. An accuracy analysis of the PI and DO methods is done on a basis of a comparison between the numerically obtained and measured temperature profiles.
\end{abstract}

Keywords: Coal combustion, heat transfer, thermal radiation, CFD techique, modelling.

\section{Introduction}

About $70 \%$ of power used throughout the world generally comes from thermal power stations. Increasing industrialization and modernization has put lot of pressure on exploration of fossil fuels such as coal, oil, and gas etc. on other hand a pollutants emitted by these power plants add to the environment affecting the habitants, flora and fauna etc. In and around the power plants as we know the pollutants such as $\mathrm{CO}_{2}, \mathrm{C} 0, \mathrm{SO}_{\mathrm{x}}$, $\mathrm{NO}_{\mathrm{x}}$ and particulate matter emits due to improper and poor combustion.

The combustion is an erotic chemical reaction where the fuel is brunt and heat is released during the process. Any improvement made such as primary air, secondary air, atomization of liquid fuels, pulverization of coal, phasing of air supply, would change phase of chemical reaction. This kind of analysis can be done by experimentation and combustion analysis obtaining appropriate models using computers. experimentation is very expensive, difficult and time consuming process development of a physical model, monitoring and control of combustion process is much more cumbersome however availability of high speed computers made easier to analysis any combustion process easy to analysis any complicated process by using computational fluid dynamics (CFD) theoretical analysis of combustion process becomes easier, cheaper and time saving. in this context some of reacher's like anes kazagić [6], u. schnell[7], w. fiveland [15] and j. m. jones, m. pourkashanian [17] , s. c. hill, l. d. smoot[22] have worked on building a mathematical models of combustion for different fuels and pollutant formation etc. still a compressive model is not available for the process of combustion in boilers.

The computational fluid dynamics (CFD) of the pulverized coal combustion field is being developed with the remarkable progress in the performance of computers. This method, in which the governing equations of the combustion field are solved using a computer, is capable to provide the detailed information on the distributions of temperature and chemical species and the behavior of pulverized coal particles over entire combustion field that cannot be obtained by experiments. In addition, it facilitates the repeated review in arbitrary conditions for the properties of pulverized coal and the flow field at a relatively low cost. It is, therefore, strongly expected that the CFD becomes a tool for the development and design of combustion furnaces and burners.

\section{Simulation Set Up And Data Input}

In ANSYS, the governing equations are discretized by using the finite Volume method The pressure velocity coupling is achieved through the SIMPLE -algorithm. The grid-independent study is done for all cases .All simulations are run in ANSYS K- $\varepsilon$ reliable model. Boundary conditions used are flue gas mass flow rate and temperature. It is assumed that all particles have attended their terminal velocity and have entered perpendicular to the tube. The geometry of actual flue gas duct, its internal, tubes created in ANSYS design modeller. Drawings of duct are used for geometry creation. Meshing is done in ANSYS meshing .Inlet surface 
meshed and volume meshing done with tetrahedral. Further refinement of mesh is done by adaption by using velocity gradient. Numbers of cells are varying as per geometry dimensions and requirement for grid independent solution. Simulation is done on existing geometry of duct first by straight vanes and then geometry by adding curved vanes.

Design data used

Table 1 - Proximate and ultimate analysis of the coal

\begin{tabular}{|l|l|}
\hline Proximate Analysis (mass fraction, dry): & \\
Volatile matter & 0.374 \\
Fixed carbon (char) & 0.543 \\
Ash & 0.083 \\
\hline Ultimate Analysis (mass fraction, as received): & \\
Carbon & 0.7369 \\
Hydrogen & 0.0466 \\
Nitrogen & 0.0133 \\
Sulphur & 0.0086 \\
Oxygen & 0.1116 \\
\hline Lower Heating Value & $29.64 \mathrm{MJ} / \mathrm{kg}$ \\
\hline
\end{tabular}

Table 2 - Coal properties

\begin{tabular}{|l|l|}
\hline Coal properties: & \\
Raw combustible density (dry) & $1560 \mathrm{~kg} / \mathrm{m}^{3}$ \\
Raw combustible specific heat (dry) & $1225 \mathrm{~J} / \mathrm{kg} \mathrm{K}$ \\
Char density (dry) & $1560 \mathrm{~kg} / \mathrm{m}^{3}$ \\
Char specific heat (dry) & $1225 \mathrm{~J} / \mathrm{kg} \mathrm{K}$ \\
Ash density (dry) & $1000 \mathrm{~kg} / \mathrm{m}^{3}$ \\
Ash specific heat (dry) & $800 \mathrm{~kg} / \mathrm{m}^{3}$ \\
\hline
\end{tabular}

\section{Numerical Simulation}

In this work, a pure two-fluid model for reacting gas-particle flows is performed, using a comprehensive eulerian treatment for both gas phase and particle phase. both velocity slip and temperature slip between coal particles and gas phase are calculated by solving the momentum equations and energy equations of gas phase and particle phase respectively. in addition, a modified k- $\varepsilon$-kp two-phase turbulence model, a secondorder moment turbulence-chemistry model for nox formation, a general model of pulverized coal devolatilization and a general model of char combustion were incorporated into the comprehensive model. for volatile and co combustion as well as radiation heat transfer, the conventional ebu-arrhenius model and the six heat-flux model were used.

\section{A. Geometry modelling}

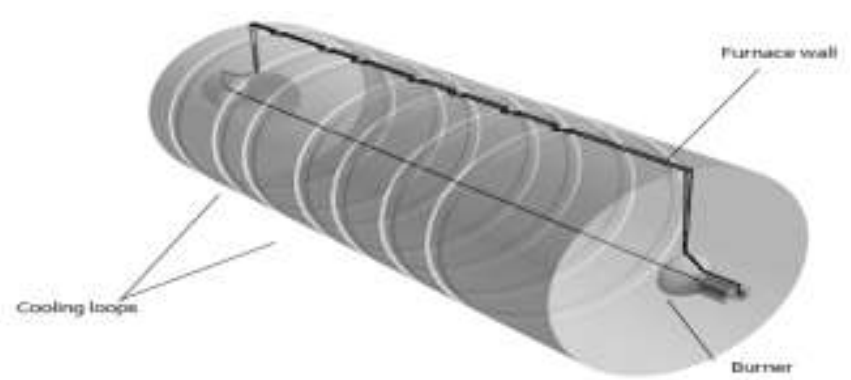

Fig. 1 Geometry of burner used in furnace showing modelled axi-symmetric section

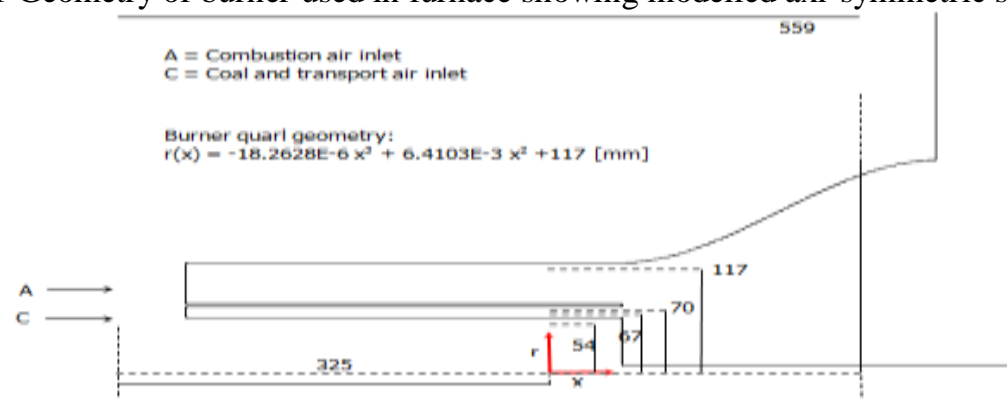

Fig. 2 Inlet and burner quarl geometry (dimensions in $\mathrm{mm}$ ) 
The outer furnace wall is cooled by a series of cooling loops, modeled in CFX as a series of cylindrical grooves of equivalent surface area. The stabilization of the coal flame is achieved by means of a swirl burner. The burner quarl is an experimental aerodynamic design whose radius is described using a cubic equation in $x$, where $x$ in this case is the axial distance from the beginning of the quarl

\section{CFX modelling details}

CFX 13 is both finite-volume based general purpose CFD codes. In CFX 13 the transport equations for mass and momentum are assembled and solved as a fully coupled system.

\section{Turbulence modelling}

The k-epsilon model was used in both codes for the gas phase turbulence

\section{Gas phase combustion}

Reaction of combusting species within the gas phase in CFX is handled within a multi-component fluid framework. A single Eulerian gas phase containing reactants and products from all gaseous reactions is used.

The Eddy Dissipation model was used for the gas phase combustion modelling, which assumes that reactions are fast and that reaction rates are limited by a mixing time determined by the properties of the turbulent eddies, i.e.

$$
\text { rate } \propto \frac{\varepsilon}{k}
$$

This mixing time appears in the equations for reactants and products limiters,

$$
\begin{aligned}
& R_{K}=A \frac{\varepsilon}{k} \min \left(\frac{[I]}{v_{K, I}}\right) \\
& R_{K}=A B \frac{\varepsilon}{k} \min \left(\frac{\sum W_{I}[I]}{\sum W_{I} v_{K, I}}\right)
\end{aligned}
$$

where $[I]$ is the molar concentration of species $I, W_{I}$ the species molecular weight and $v_{K, I}$ the stoichiometric coefficient of species $I$ in elementary reaction $K$. The minimum of

these limiters determines the rate of the reaction. The magnitude of the limiters is controlled by two model coefficients, $A$ and B. The default value for $A$ in CFX is 13.0 and this is appropriate for a wide range of combusting flows. However, for swirling, turbulent diffusion flames, Visser [20] recommends a value of 0.6. This value was therefore used for the CFX simulations.

\section{B Meshing}

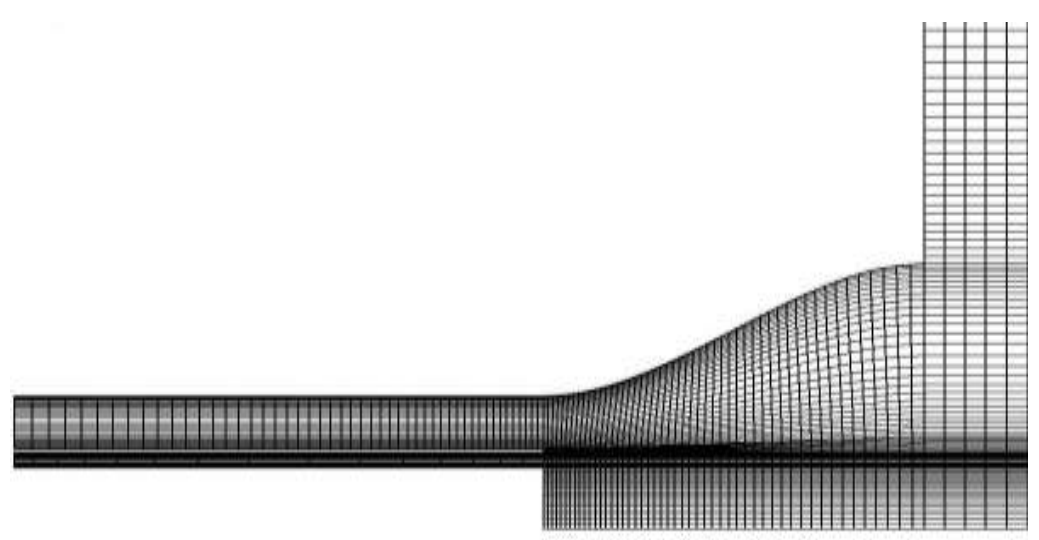

Figure 3 - Mesh resolution near inlet and burner quarl region

The numerical grid was generated by creating a block-structured representation of the axi-symmetric geometry using CFX-4 Build. The swept angle used for the mesh was 5 degrees in in ANSYS MEshing. The resulting 3D mesh was one element thick and consisted entirely of hexahedral element types.

The total number of nodes in the mesh was 104137 and the total number of elements was 51652. In CFX 11, the elements at the axis were degenerate hex elements (i.e. wedge elements). This number of nodes is large enough to ensure grid-independent solutions in the near-burner zone. 
Boundary conditions

The coal analyzed was a typical high yield material. Coal particle sizes were assumed to obey a RosinRammler type distribution (Table 3)

\begin{tabular}{|l|l|}
\hline \multicolumn{2}{|c|}{ Table 3 - Coal particle sizes } \\
\hline Particle properties & \\
\hline Distribution type & Rosin Rammler \\
\hline Mean particle size & 45 microns \\
\hline Particle spread & 1.36 \\
\hline
\end{tabular}

The conditions used for the combustion air burner inlet are shown in Table 3. The modelled profile of tangential velocity is specified as a function of radius, and is based on calibrated probe data in the original experiments.

Table. 4 - Combustion air input conditions

\begin{tabular}{|l|l|}
\hline Combustion air inlet conditions & \\
\hline Mass Flow Rate (dry) & $2684 \mathrm{~kg} / \mathrm{hour}$ \\
\hline Temperature & $573 \mathrm{~K}$ \\
\hline Axial velocity & $43.83 \mathrm{~m} / \mathrm{s}$ \\
\hline Mean tangential velocity & $49.42 \mathrm{~m} / \mathrm{s}$ \\
\hline Tangential velocity profile & $528.56 \mathrm{r} \mathrm{m} / \mathrm{s}$ \\
\hline Turbulence Intensity & $20 \%$ \\
\hline Turbulence length scale & $47 \mathrm{~mm}$ \\
\hline
\end{tabular}

The conditions used at the pulverized coal and transport air inlet are shown in Table 5

Table 5 - Transport air and coal input conditions

\begin{tabular}{|l|l|}
\hline Coal gun input conditions & \\
\hline Coal mass flow rate & $263 \mathrm{~kg} / \mathrm{hour}$ \\
\hline Air mass flow rate & $421 \mathrm{~kg} / \mathrm{hour}$ \\
\hline Temperature & $343.15 \mathrm{~K}$ \\
\hline Mean axial velocity & $23.02 \mathrm{~m} / \mathrm{s}$ \\
\hline Turbulence intensity & $10 \%$ \\
\hline Turbulence length scale & $13 \mathrm{~mm}$ \\
\hline
\end{tabular}

The thermal boundary conditions applied to the walls of the furnace are detailed in Table 6 .

Table 6 - Furnace wall thermal boundary conditions

\begin{tabular}{|l|c|c|}
\hline \multicolumn{1}{|c|}{ Boundary } & Temperature $(\mathrm{K})$ & Emissivity \\
\hline Inlet duct & $343 / 573$ & 0.6 \\
\hline Coal gun front & 800 & 0.6 \\
\hline Burner quarl & 1273 & 0.6 \\
\hline Furnace front & 1400 & 0.5 \\
\hline Furnace cylinder & 1400 & 0.5 \\
\hline Cooling loops & 1000 & 0.4 \\
\hline Furnace back & 1300 & 0.5 \\
\hline Chimney & 1300 & 0.5 \\
\hline
\end{tabular}

The symmetrical boundaries in the azimuthal direction were given periodic flow conditions. This is required to model the effect of the swirl component.

\section{Result And Discussion}

The numerical model is based on the solution of transport equations for main chemical species $\left(\mathrm{O}_{2}\right.$, $\mathrm{CO}_{2}, \mathrm{CO}, \mathrm{H}_{2} \mathrm{O}$ and volatile species e.g. tars, enthalpy) the three gas momentum components and for the turbulent kinetic energy $\mathrm{k}$ and its dissipation rate e. Pressure is calculated from the continuity equation using the PISO algorithm. The source term due to the heat transferred by radiation is calculated using the discrete heat transfer model considering scattering and a suitable package to evaluate the radioactive properties of the gas- 
particle mixture. The calculation of the front wall fired boilers was extended compared to the previous projects by considering the upper section of the furnace where pendent super heater panels exist.

The coal particles are described by a stochastic Lagrangian procedure to integrate the equation of motion and the energy balance, together with the consideration of physical models. The coal evolution is described in sequence by drying, pyrolysis and char combustion. For volatile release a parallel reaction scheme is used. For char combustion a first order kinetic rate combined with a diffusion resistance is used, considering the particle diameter constant. The kinetic rate for char combustion has been considered as a function of burnout according to $\mathrm{k}=4 \mathrm{k} 0(1-\mathrm{BO})^{2}$ which is an approximate fit to data observed in drop tube furnaces.

Initially flow inside burner is carried out because complete boiler study is cobutationaly expensive and setting up and solving a coal combustion case with the Eddy Break Up (EBU) model.

Steps

- Set up and solve a coal combustion case.

- Use the Eddy Break Up (EBU) model.

- Solve the case using appropriate solver settings.

- Postprocess the resulting data.

And results are presented.
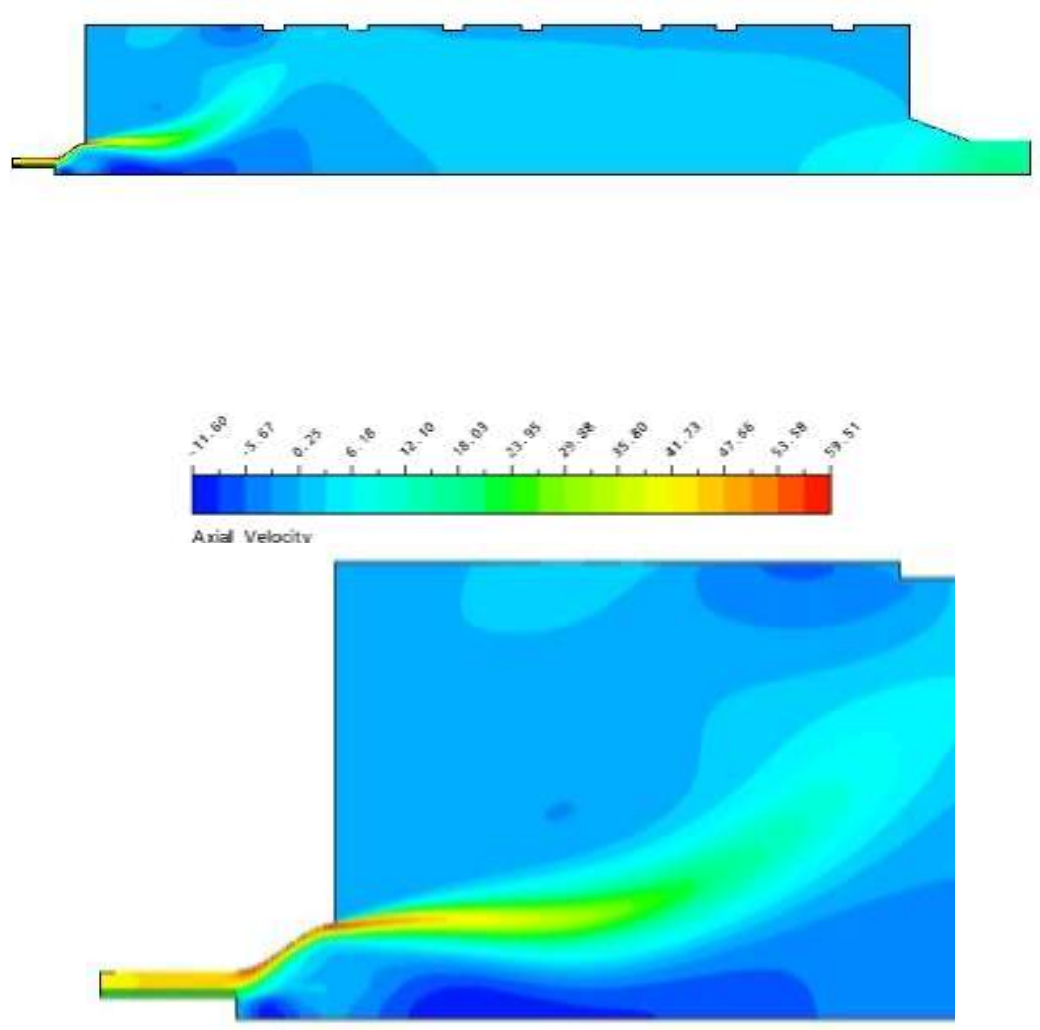

Fig. 1 Axial velocity distribution

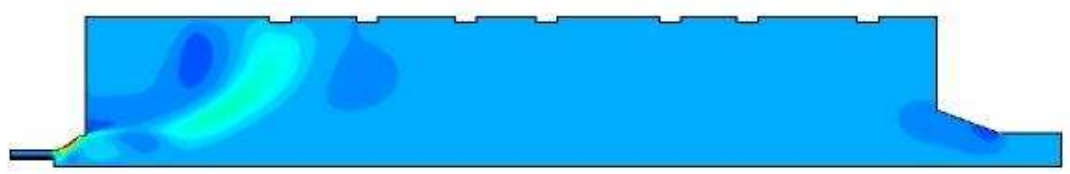



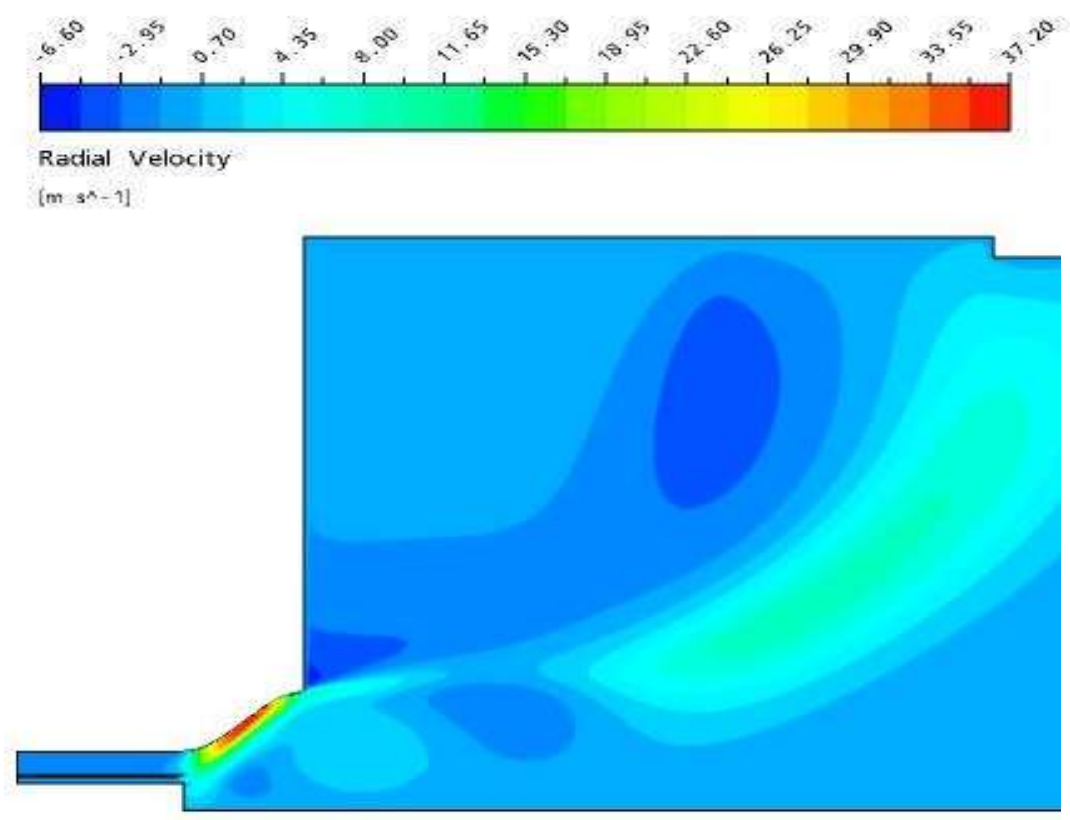

Fig. 2 Radial velocity distribution
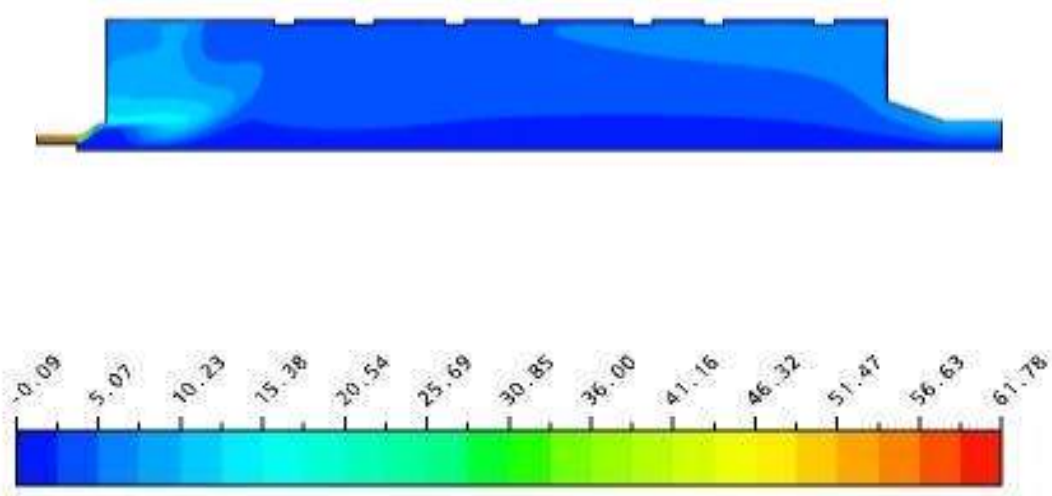

Tangential Velocity

[m $\left.s^{x}-1\right]$

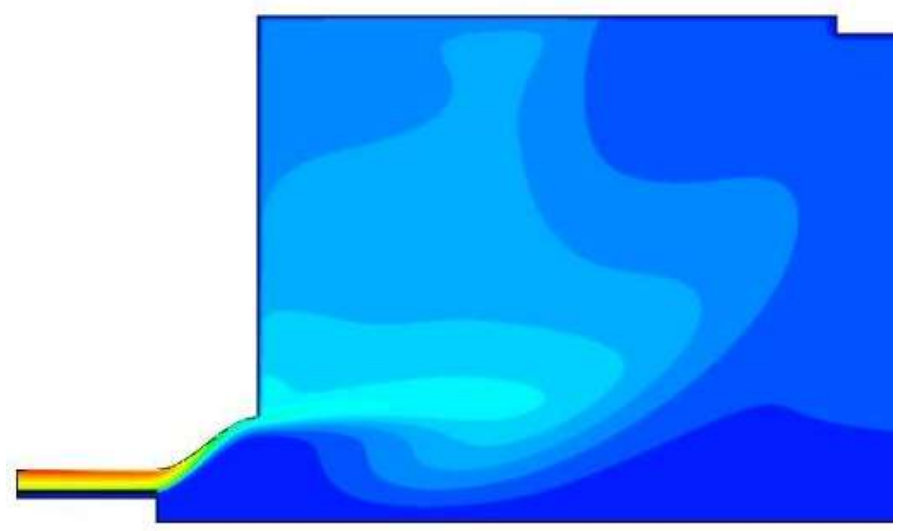

Fig. 2 Tangential velocity distribution 
Variation of gas temperature distribution (k)
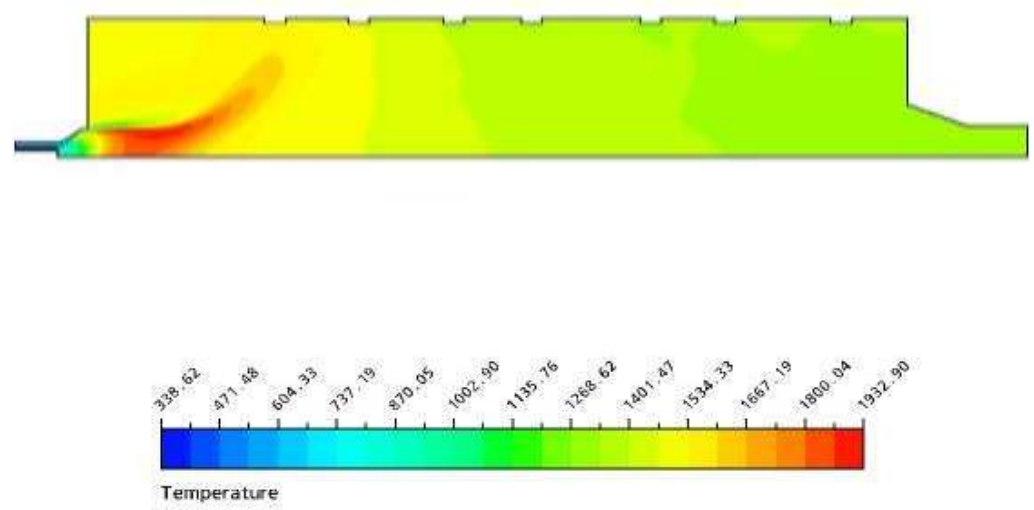

[K]

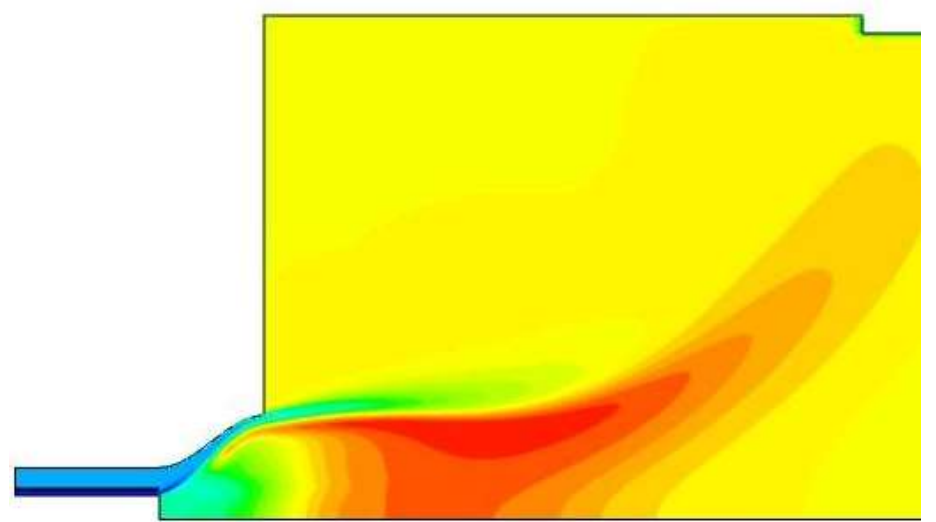

Fig. 3 Gas temperature distribution

Variation of Oxygen mass fraction distribution
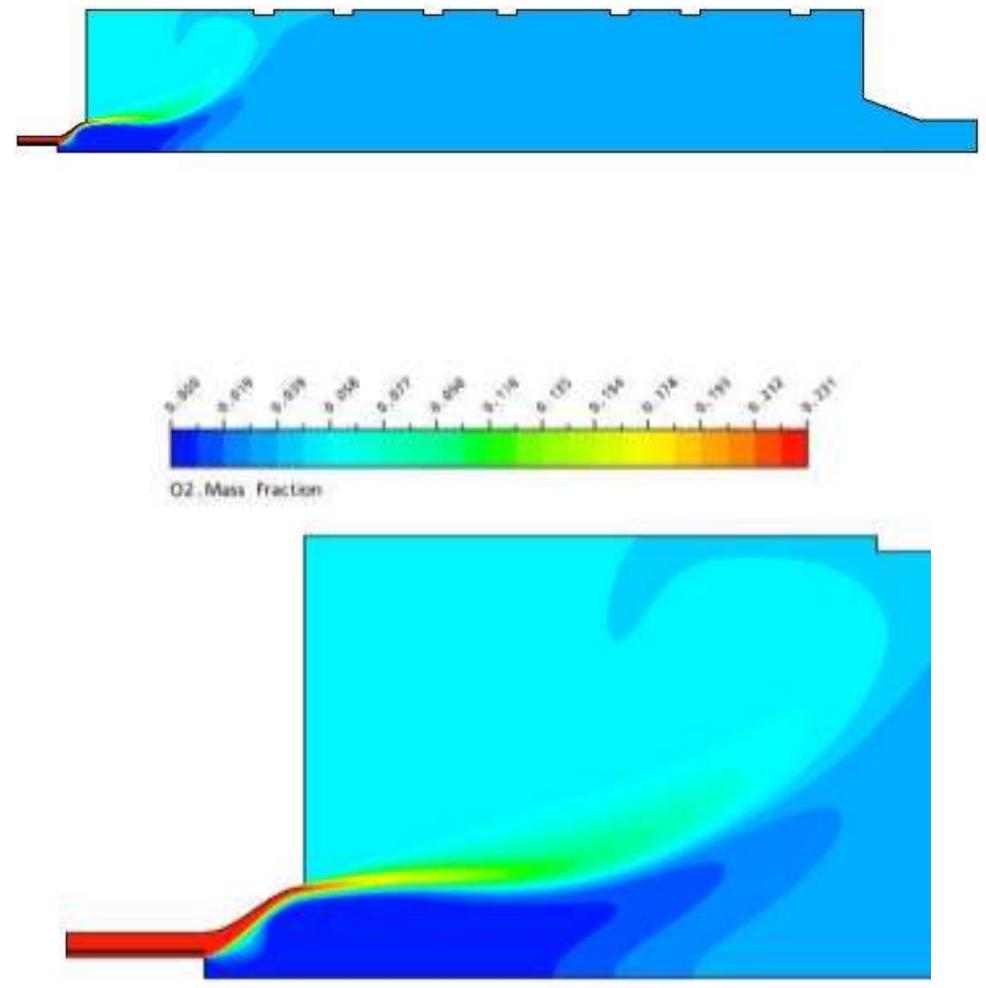

Fig. 4 Oxygen mass fraction distribution 


\section{Variation of Carbon dioxide mass fraction distribution}
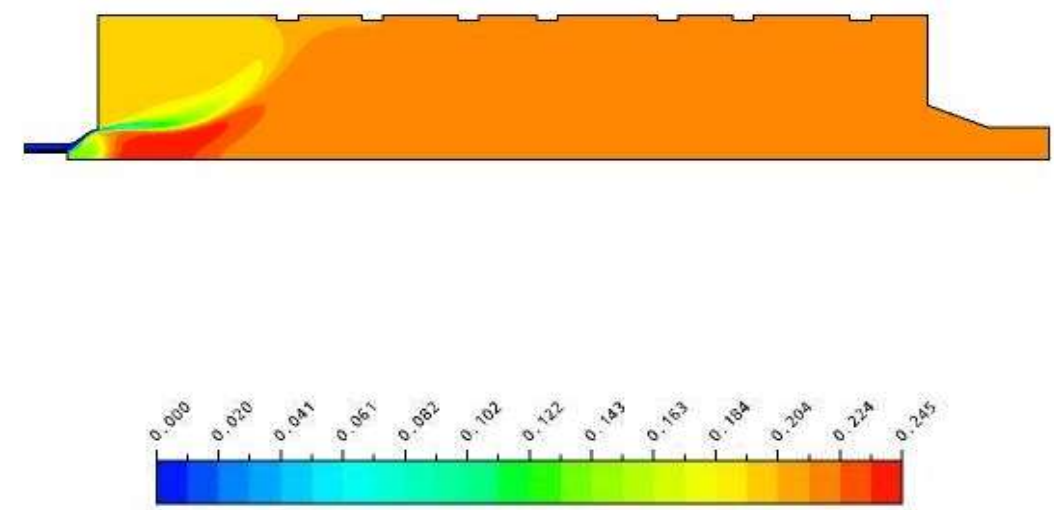

CO2. Mass Fraction

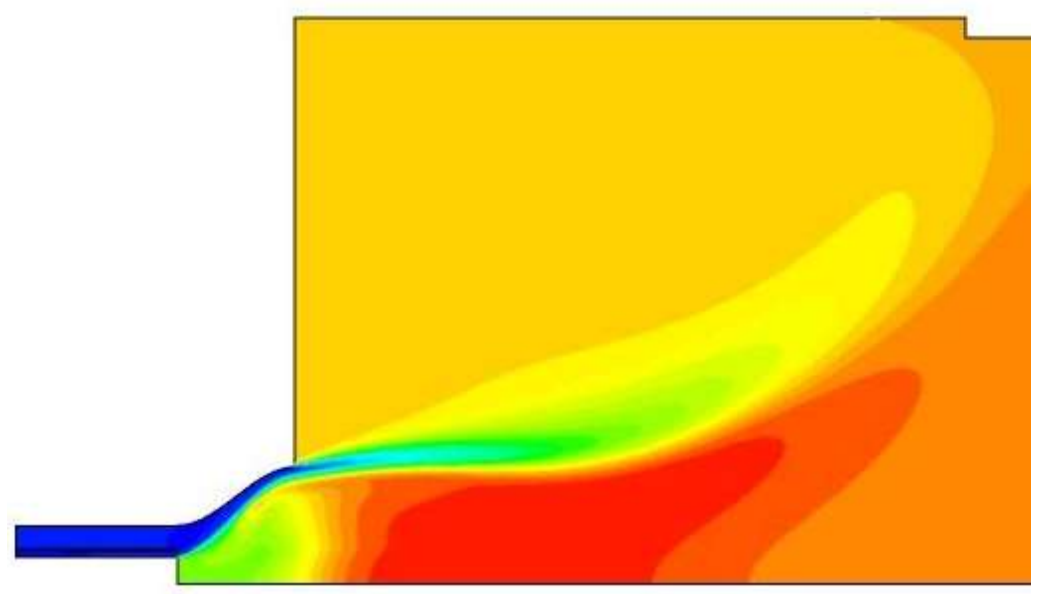

Fig. 5 Carbon dioxide mass fraction distribution

Variation of Water mass fraction distribution
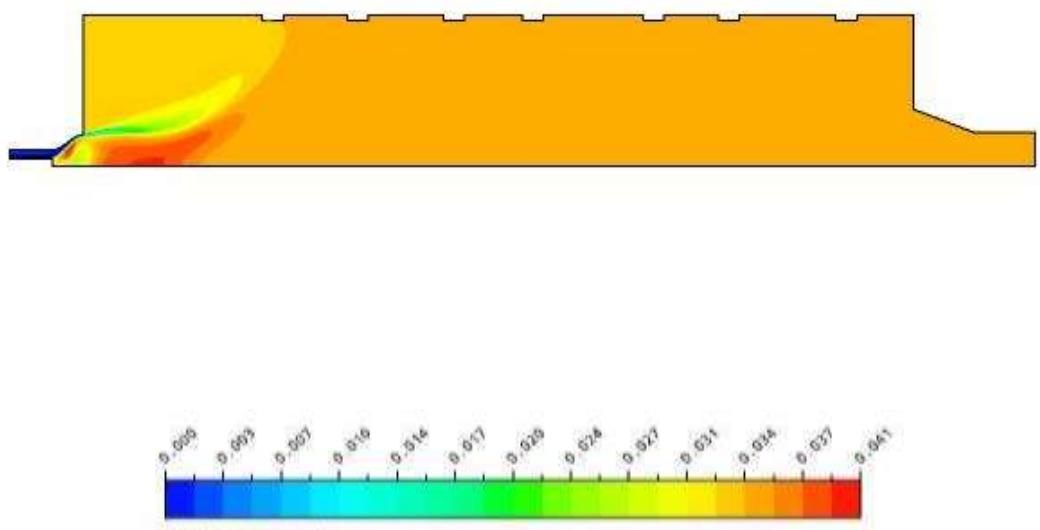

H2O Mass Fraction

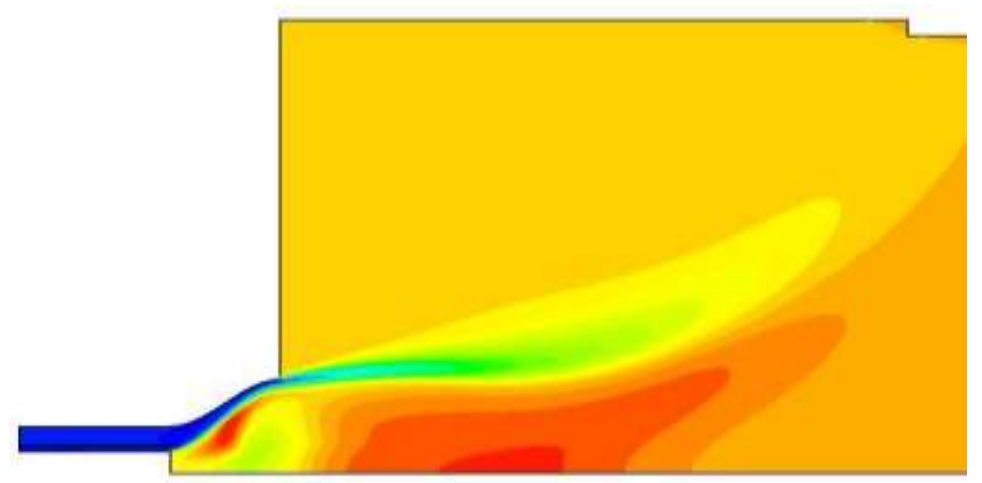

Fig. 6 Water mass fraction distribution 
Coal particle tracks coloured by particle temperature: Discrete Transfer
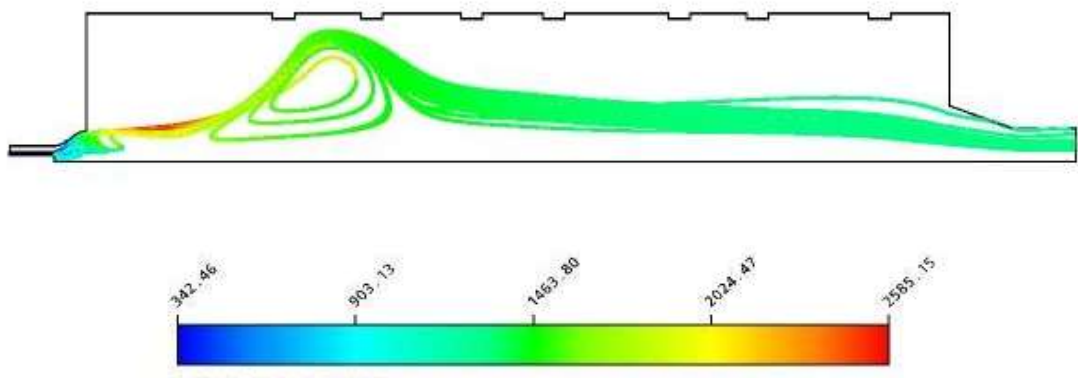

HC Fuel, Temperature

[K]

Fig.7 Coal particle tracks coloured by particle temperature: Discrete Transfer

Coal particle tracks coloured by particle temperature: Discrete ordinate
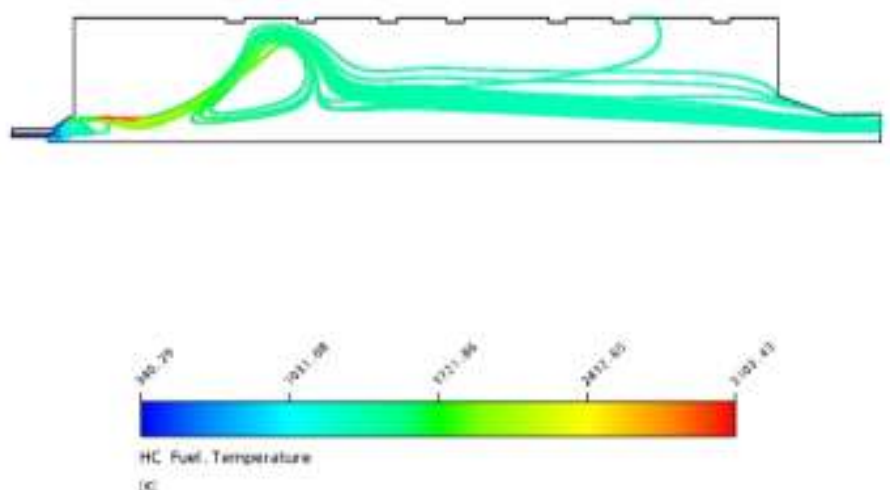

Fig.8 Coal particle tracks coloured by particle temperature: Discrete ordinate

Coal particle tracks coloured by particle temperature: P1
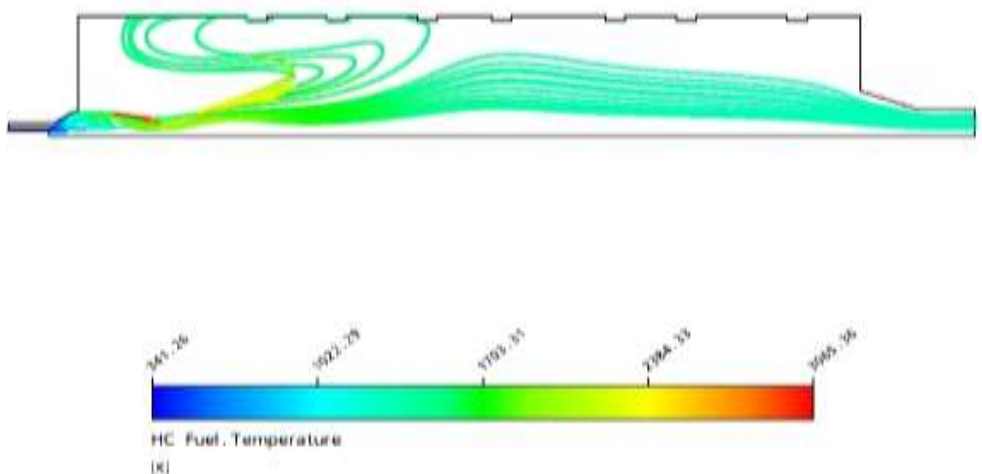

Fig. 9 Coal particle tracks coloured by particle temperature: P1

\section{Conclusion}

The main objective of the present study was to investigate how the results obtained with three radiative heat transfer methods, the P1 approximation method, Discrete transfer and the DO method, fit the temperature field in a boiler furnace on pulverized coal, with implemented OFA ports. Despite the evident discrepancies, in general, the both thermal radiation modeling approaches, with the DO, DT and the P-1 models, give fair representation of the experimental results. The obtained temperature profiles with P-1 model are somewhat lower than in the case when DO model is used. In that sense, the results obtained with the DO, DT model better fit the measurements. The main differences between the modeling and the measurement values appear in the burnout zone, near the air/fuel injections, and need further investigation for appropriate explanation. In general, they can be addressed to several reasons: peculiarities of the flow field in the near-burner region, including the particles-turbulence interaction; the utilized thermal radiation models; and the variability of coal properties that requires much characterization data for validation purposes of the boiler furnace processes. Finally, it must be noted that the computation with the DO and DT model is more time consuming. 


\section{Reference}

[1] A. Williams, R. Backreedy, R. Habib, J. M. Jones and M. Pourkashanian, Fuel. 81 (5), 605-618 (2002).

[2] A. Arenillas, R. I. Backreedy, J. M. Jones, J. J. Pis, M. Pourkashanian, F. Rubiera and A. Williams, Fuel. 81 (5), 627-636 (2002).

[3] A. M. Carpenter, IEACR/81. IEA Coal Research, London, 1995.

[4] J. M. Beer, Progress in Energy and Combustion Science. 26, 301-327 (2000).

[5] A. M. Eaton, L. D. Smoot, S. C. Hill and C. N. Eatough, Progress in Energy and Combustion Science. 25, 387-436 (1999).

[6] Anes Kazagić, Izet Smajević, Neven Duić, SELECTION OF SUSTAINABLE TECHNOLOGIES FOR COMBUSTION OF BOSNIAN COALS, THERMAL SCIENCE YEAR 2010, VOLUME 14, ISSUE 3, PAGES [715 - 727]

[7] U. Schnell, "Numerical modelling of solid fuel combustion processes using advanced CFD-based simulation tools", Progress in Computational Fluid Dynamics, Vol. 1, No. 4, pp. 208-218, 2001.

[8] Launder, B.E., Priddin, C.H., and Sharma, B.I. J Fluid Engineering 1979, 99, 363

[9] Khalil, E.E. Modeling of Furnace and Combustors, Abacus Press, 1982

[10] Y. A. Zhuravlev, F. K. Sidorov, M. Y. Protsaylo, "Primenenie zonalynogo metoda dlya rascheta teploobmena v topke kotla", Teploenergetika, No 11, pp. 35-39, 1980.

[11] M. Y. Protsaylo, Y. A. Zhuravlev, "Issledovanie zonalynyim metodom vliyaniya rezhimnyih parametrov na teploobmen v topke kotla P-67", Teploenergetika, No. 4, pp. 13-16, 1983.

[12] Levy, J.M., Chan, L.K., Sarofim, A.F., and Beer, J.M. Eighteenth Symposium (Int.) on Combustion. Pittsburgh, PA, The Combustion Institute, 1981, 111.

[13] Smith, P.J., Hill, S.C., and Smoot, L.D. Nineteenth Symposium (Int.) on Combustion. Pittsburgh, PA, The Combustion Institute, $1982,1263$.

[14] G. Blokh. Heat Transfer in Steam Boiler Furnaces, London, Hemisphere Publishing, 1988.

[15] P. Ustimenko, K. B. Dzhakupov, V. O. Kroly, Chislennoe modelirovanie aerodinamimki i goreniya v topochnyih i tehnologicheskih ustroystvah, Izd. "Nauka", Alma Ata, 1986.

[16] W. Fiveland, A. R. Wessel, "Numerical model for predicting performance of three-dimensional pulverized-fuel fired furnaces", Journal of Engeneering for Gas Turbines and Power, Vol. 110(11),mpp. 117-126, 1988.

[17] J. Fan, L. Qian, Y. Ma, P. Sun, K. Cen, "Computational modeling of pulverized coal combustion processes in tangentially fired furnaces",mChemical Engineering Journal, Vol. 81(1), pp. 261-269, 2001.

[18] J. M. Jones, M. Pourkashanian, A. Williams, R. K. Chakraborty, J. Sykes, D. Laurence, "Modelling of coal combustion processes - a review of present status and future needs", In Proc. 15th Annu. Intern. Pittsburgh Coal Conf. Pittsburgh, 1998; pp. 1-20.

[19] Peters, A.A.F and Weber, R, Mathematical Modeling of a 2.4 MW Swirling Pulverized Coal Flame, Combustion Science and Technology, 1997, Vol. 122, pp. 131-182.

[20] Badzioch, S., and Hawksley, P.G.W., Kinetics of thermal decomposition of pulverised coal particles, Industrial Engineering Chemistry Process Design and Development, 9 p.521, 1997.

[21] Visser, B.M., Smart, J.P., van de Kamp and Weber, R., Measurements and predictions of quarl zone properties of swirling pulverized coal flames, 23rd Symp. (Int.) on Comb., The Combustion Institute, p. 949.

[22] R. K. Boyd, J. H. Kent, "Three-dimensional furnace computer modelling”, Proceedings of the 21st Symposium (Int.) on Combustion, The Combustion Institute, Pittsburgh, 1986, pp. 265-274.

[23] S. C. Hill, L. D. Smoot, “A comprehensive three-dimensional model for simulation of combustion systems: PCGC-3", Energy \& Fuels, Vol. 7(6), pp.874-883, 1993.

[24] X. Y. Zhou, C. G. Zheng, Y. Y. Ma, "comparison of several discrete arithmetic schemes for simulating a constrained jet and a labscale tangential fired furnace", Computer Methods in Applied Mechanics and Engineering, Vol. 130(3-4), pp.279-288, 1996.

[25] A. Bermudez de Castro, J. L. Ferin, "Modelling and numerical solution of a pulverized coal furnace", Proceedings of the $4^{\text {th }}$ International Conference on Technologies and Combustion for Clean Environment, Lisbon, Portugal, paper 33.1, 1997, pp. 1-9.

[26] L. X. Zhou, L. Li, R. X. Li, J. Zhang, "Simulation of 3-d gas-particle flows and coal combustion in a tangentially fired furnace using a two-fluid-trajectory model", Powder Technology, Vol. 125(2), pp. 226-233, 2002.

[27] Yin, S. Caillat, J. L. Harion, B. Baudoin, E. Perez, "Investigation of the flow, combustion, heat-transfer and emissions from a 609 mw utility tangentially fired pulverized coal boiler", Fuel, Vol. 81(8), pp.997-1006, 2002.

[28] W. A. Fiveland, "Three-dimensional radiative heat-transfer solutions by the discrete-ordinates method", Journal of Thermophysics, Vol. 2, No. 4, pp. 309-316, Oct. 1988.

[29] He, M. Chen, Q. Yu, S. Liu, L. Fan, S. Sun, J. Xu, W. P. Pan, "Numerical study of the optimum counter-flow mode of air jets in a large utility furnace", Computers \& Fluids, Vol. 33 (9), pp.1201- 1223, 2004

[30] J. Pallares, I. Arauzo, A. Williams, "Integration of CFD codes and advanced combustion models for quantitative burnout determination", Fuel, Vol. 86, No. 15, pp. 2283-2290, Oct. 2007.

[31] H. Knaus, U. Schnell, K.R.G. Hein, "On the modelling of coal combustion in a 550 MWel coal-fired utility boiler", Progress in Computational Fluid Dynamics, Vol. 1, No. 4, pp. 194-207, 2001.

[32] C. Ratzel III, J. R. Howell, "Two-dimensional radiation in absorbing-emitting media using the p-n approximation", Journal of Heat Transfer, Transactions of the ASME, Vol. 105, pp.333-340, 1983.

[33] R. V. Filkoski, I. J. Petrovski, P. Karas, "Optimisation of pulverized coal combustion by means of CFD/CTA modelling", Thermal Science (An International Journal), Vol. 10, No. 3, pp.161-179, 2006. 